\title{
RANTAI NILAI PADA BUDIDAYA KOLAM IKAN AIR TAWAR DI KOTA BOGOR
}

\author{
VALUE CHAIN IN CULTIVATION OF FRESH WATER FISH IN THE CITY OF BOGOR
}

\author{
Arief Nur Rakhman*), Muhammad Firdaus ${ }^{* *}$, dan Rina Oktaviani**) \\ *) PT Mesitechmitra Purnabangun (MESITECH) \\ Jl. RS. Fatmawati No. 39 Jakarta 12150 \\ ${ }^{* *}$ Departemen Ilmu Ekonomi, Fakultas Ekonomi dan Manajemen, Institut Pertanian Bogor \\ Jl. Agatis Kampus IPB Darmaga, Bogor 16680
}

\begin{abstract}
This study was conducted to determine the flow of the value chain of freshwater fish pond culture in the city. Research on the value chain actors freshwater fish farming in Bogor, mapping the value chain, the production cost and the Marginal value of the value chain. Actors involved in the value chain of freshwater fish farming pond in the city of Bogor is fish farmers, collectors and traders. From the analysis of the Margin, the mediator has the greatest Margin value.
\end{abstract}

Keywords: fish culture, value chain, freshwater fish, value-chain analysis (VCA)

\begin{abstract}
Abstrak: Penelitian ini dilakukan untuk mengetahui alur rantai nilai budidaya kolam ikan air tawar di Kota. Anlisis penelitian yang digunakan adalah analisis rantai nilai/value-chain analysis (VCA). Hasil penelitian menunjukkan secara umum pada rantai nilai budi daya ikan ini yang mendapatkan margin terbesar ada pada aktor pengepul, dimana pengepul yang mempunyai akses dan informasi dua arah, baik itu informasi pasar ataupun informasi mencari petani ikan.
\end{abstract}

Kata kunci: budi daya ikan, rantai nilai, ikan air tawar, value-chain analysis (VCA)

\footnotetext{
${ }^{1}$ Alamat Korespondensi:

Email: ariefanr@gmail.com
}

\section{PENDAHULUAN}

Sektor pertanian merupakan salah satu sektor yang sangat penting dalam proses pembangunan ekonomi negara. Dengan memanfaatkan dan mengelola sumberdaya alam lingkungan dengan baik, pembangunan ekonomi di suatu negara itu pun akan berjalan baik. Jika ingin melihat melihat pertumbuhan perekonomian suatu Negara, salah satu cara yang bisa dilakukan dengan melihat PDB negara tersebut. Indonesia mempunyai sektor yang bisa digunakan untuk pengukuran PDB. Pada tahun 2014 Sektor Pertanian, Peternakan, Kehutanan, dan Perikanan berada di urutan ketiga dengan nilai 350.722,2 (Milliar Rupiah), nilai tersebut di bawah dari sektor Perdagangan, Hotel, dan Restoran sebesar 524.309,5 (Milliar Rupiah). Akan tetapi, jika dilihat laju pertumbuhan sektor Pertanian, Peternakan, Kehutanan, dan Perikanan mempunyai nilai yang konstan sejak tahun 2010-2014 (BPS, 2014). Jika dilihat pada sektor Pertanian, Peternakan, Kehutanan, dan Perikanan tahun 2014 nilai laju pertumbuhan terbesar ada pada subsektor perikanan dengan laju pertumbuhan sebesar $6,82 \%$, hal itu pun terjadi dalam kurung waktu lima tahun terakhir walaupun nilai setiap tahunnya fluktuatif akan tetapi laju pertumbuhan dari sub-sektor perikanan selalu terbesar di dalam sektor Pertanian, Peternakan, Kehutanan, dan Perikanan. Kegiatan perikanan dilaksanakan dalam berbagai kegiatan, seperti penangkapan, pembudidayaan, pengolahan, pemasaran, penelitian dan kegiatan perikanan lainnya.

Budi daya adalah suatu seni atau kreasi manusia untuk memelihara, membesarkan dan menumbuhkan organisme dalam perairan secara terkontrol, atau kreasi manusia memadukan ilmu dan teknologi untuk memanipulasi sumber daya perairan dan sumber daya ikan bagi keperluan kesejahteraan masyarakat (Cahyono, 2001). Budi daya perikanan telah menjadi industri yang berkembang pesat karena adanya 
peningkatan permintaan yang signifikan untuk memenuhi gizi manusia (Urbasa, 2015).

Sejak tahun 2010 hingga tahun 2013, produksi ikan di Indonesia dikuasi dari subsektor perikanan budidadaya (BPS, 2014). Menurut data Badan Pusat Statistik tahun 2014 provisi Jawa Barat merupakan provinsi yang mempunyai jumlah produksi ikan dari budi daya kolam paling besar di indonesia, pada tahun 2013 Provinsi Jawa Barat memproduksi sebanyak 424.231 ton ikan dari budi daya kolam. Kota Bogor merupakan salah satu kota penyumbang produksi perikanan air tawar di jawa barat. Pada tahun 2013 produksi ikan di kota bogor mencapai 4.238.02 ton, dan sebagaian besar dihasilkan dari budi daya kolam, yaitu sekitar $84,28 \%$ atau sebesar 3.571.89 ton. Sejak tahun 2011-2013 jumlah produksi ikan budi daya kolam di bogor terus meningkat dengan memiliki luas area sekitar 75 hektar lahan untuk budi daya kolam pada tahun 2013 dan tinggi permintaan pasar terhadap ikan serta ditunjung dengan Kota Bogor mempunyai letak yang strategis dikarenakan dekat dengan pasar potensial (Jakarta) sehingga Kota Bogor masih bisa berpotensi meningkatkan jumlah produksi ikan dan menciptakan produk dari budi daya kolam air tawar yang mempunyai keungulan kompetitif. Kepercayaan terhadap ikan sebagai sumber protein hewani yang baik telah menjadikan ikan sebagai nilai yang dianut dan dipertahankan oleh responden sebagai preferensi pribadinya dalam memilih sumber protein hewani (Sokib, 2012).

Shank dan Govindarajan (2000) mendefinisikan value chain analyisis merupakan alat untuk memahami rantai nilai yang membentuk suatu produk. Rantai nilai ini berasal dari aktivitas-aktivitas yang dilakukan, mulai dari bahan baku sampai ke tangan konsumen, termasuk juga pelayanan purna jual. Porter (1985) menjelaskan bahwa value chain analysis merupakan alat analisis stratejik yang digunakan untuk memahami secara lebih baik terhadap keunggulan kompetitif.

Beberapa penelitian yang terdahulu yang dijadikan dasar penelitian maupun pembanding dalam penelitian ini antara lain penelitian Kusumawati dan Santosa (2013) yang menganalisis mengenai Rantai Nilai (value chain) Agribisnis Labu di Kecamatan Getasan Kabupaten Semarang. Penelitian ini bertujuan untuk mengetahui rantai nilai labu dan mengetahui strategi untuk mengeksiskan posisi agribisnis labu. Dalam penelitian ini digunakan beberapa teori, yaitu teori rantai nilai, teori produksi, dan teori biaya. Hadiwidjojo
(2016) melakukan penelitian yang berjudul rantai nilai pada CV master sentra boga. Penelitian ini bertujuan untuk menganalisis aktivitas-aktivitas bisnis yang dilakukan oleh CV Master Sentra Boga yang terdiri dari aktivitas utama dan aktivitas pendukung untuk menyusun rantai nilai dari CV Master Sentra Boga. Jenis penelitian Variabel yang diteliti adalah biji labu, pupuk kandang, tenaga kerja, biaya transportasi, dan harga labu.

Penelitian tentang rantai nilai juga pernah dilakukan oleh Pambudi (2012) dengan melakukan analisis rantai nilai untuk menentukan strategi daya saing produk manisan carica dieng. Penelitian ini bertujuan untuk memahami tahapan dan kondisi dari rantai nilai (value chain) produk manisan carica yang selanjutnya akan digunakan untuk menentukan strategi untuk meningkatkan daya saing industri manisan carica. Arvianto (2013) melakukan penelitian tentang usulan strategi untuk meningkatkan daya saing produk mebel rotan single chair dengan analisis rantai nilai. Berdasarkan uraian permasalahan maupun penelitian terdahulu maka tujuan dari penelitian ini adalah menganalisis rantai nilai budi daya kolam air tawar di Kota Bogor.

\section{METODE PENELITIAN}

Penelitian ini dilakukan di Kota Bogor, Jawa Barat. dimana di daerah tersebut merupakan salah satu Kota dalam memproduksi ikan dari budi daya kolam ikan air tawar di Jawa Barat. Penelitian ini dilaksanakan pada Bulan Oktober-Desember 2015.

Pendekatan penelitian ini menggunakan metode deskriptif berdasarkan studi kasus budi daya kolam air tawar di kota Bogor. Kegiata Observasi dilakukan dengan meninjau dan mengumpulkan informasi dari aktivasi rantai nilai budi daya kolam air tawar di Kota Bogor. Data yang diperoleh akan dianalisis secara kualitatif dan kuantitatif tujuannya untuk mengkaji dan memperoleh gambaran mengenai rantai nilai dan faktor-faktor penentu keunggulan kompetitif budi daya kolam air tawar.

Jenis data yang dikumpulkan terdiri dari dua jenis, yaitu data primer dan data sekunder. Data primer diperoleh melalui wawancara mendalam dan pengisian kuesioner oleh responden yaitu pakar dan praktisi budi daya kolam di Kota Bogor. Pengisian kuesioner dilakukan 
untuk memperoleh informasi aplikasi rantai nilai budi daya kolam di Kota Bogor.

Data sekunder diperoleh dari studi pustaka mulai dari jurnal, buku, serta laporan data yang dikeluarkan oleh pemerintah. Data sekunder yang digunakan adalah data umum yang mendukung penelitian baik internal maupun eksternal budi daya kolam air tawar di Kota Bogor.

Teknik pengambilan contoh dengan menggunakan salah satu metode non probability sampling (pengambilan sampel non acak/disengaja), yaitu purposive sampling dengan memilih 1 petani pada setiap kecamatan di Kota Bogor, dengan kriteria minimal sudah melakukan usaha budi daya kolam 10 tahun. Kriteria pakar yang akan diteliti yaitu memiliki pengetahuan dan/atau memiliki pengalaman tentang obyek yang diteliti. Pakar dan praktisi yang dipilih adalah yang terkait dengan budi daya kolam air tawar. Penelitian ini mengambil enam responden untuk petani budi daya kolam air tawar, satu responden untuk tiap aktor lainnya dengan menggunakan teknik snowball sampling dan total responden pada penelitian sebanyak 11 responden (Tabel 1).

Tabel 1. Data responden

\begin{tabular}{|c|c|c|}
\hline Kategori/Jabatan & Jumlah & Jenis data \\
\hline Petani & 6 & $\begin{array}{l}\text { Kegiatan rantai nilai, } \\
\text { aktivitas produksi }\end{array}$ \\
\hline Pengumpul & 1 & $\begin{array}{l}\text { Kegiatan rantai nilai, } \\
\text { aktivitas produksi }\end{array}$ \\
\hline $\begin{array}{l}\text { Pedagang } \\
\text { Pengecer }\end{array}$ & 1 & $\begin{array}{l}\text { Kegiatan rantai nilai, } \\
\text { aktivitas pasokan, produksi, } \\
\text { pemasaran, kondisi } \\
\text { sumberdaya, permintaan, } \\
\text { industri, kesempatan, peran } \\
\text { pemerintah, strategi bersaing }\end{array}$ \\
\hline $\begin{array}{l}\text { Fakultas } \\
\text { Perikanan Institut } \\
\text { Pertanian Bogor }\end{array}$ & 1 & $\begin{array}{l}\text { Kondisi sumberdaya, } \\
\text { permintaan, industri, } \\
\text { kesempatan, peran } \\
\text { pemerintah, strategi bersaing }\end{array}$ \\
\hline $\begin{array}{l}\text { Dinas Pertanian } \\
\text { Kota Bogor }\end{array}$ & 2 & $\begin{array}{l}\text { Kondisi sumberdaya, } \\
\text { permintaan, industri, } \\
\text { kesempatan, peran } \\
\text { pemerintah, strategi bersaing }\end{array}$ \\
\hline
\end{tabular}

Dalam menjawab tujuan penelitian digunakan analisis rantai nilai/value-chain analysis (VCA) dengan berupaya memahami bagaimana suatu bisnis menciptakan nilai bagi pelanggan dengan memeriksa kontribusi dari aktivitas-aktivitas yang berbeda dalam bisnis terhadap nilai tersebut. VCA mengambil sudut pandang proses, analisis ini membagi bisnis menjadi kelompok-kelompok aktivitas yang terjadi dalam bisnis tersebut; diawali dengan input yang diterima oleh perusahaan dan berakhir dengan produk atau jasa perusahaan dan layanan purnajual bagi pelanggan. VCA berupaya melihat biaya lintas rangkaian aktivitas yang dilakukan oleh bisnis tersebut untuk menentukan dimana terdapat keunggulan biaya rendah atau kelemahan biaya. Analisis rantai nilai diawali dengan analisis pemetaan menggambarkan keterkaitan di antara aktor, prosesor dan aktivitas di dalam rantai nilai. Analisis ini juga untuk menggambarkan tingkat ketergantungan aktor dan prosesor dan menciptakan kesadaran pemangku kepentingan tentang keterlibatannya di dalam rantai nilai (Mmasa et al. 2012). Pola rantai nilai budi daya kolam ikan air tawar dipetakan dengan menggunakan metode observasi dan wawancara mendalam terhadap aktor pelaku rantai nilai budi daya kolam ikan air tawar di kota Bogor. Kerangka pemikiran penelitian selengkapnya pada Gambar 1.

\section{HASIL}

Analis rantai nilai pada budi daya kolam ikan air tawar di Kota Bogor terdapat tiga aktor utama: aktor yang berperan terdiri dari petani, pengepul, serta pedagang. Masing-masing aktor mempunyai peran yang berbedabeda sesuai dengan kepentingan dan kebutuhannya masing-masing. Setiap aktor mempunyai hubungan yang sangat kuat dalam berjalannya rantai nilai ini, apabila satu aktor ada yang mempunyai kendala maka akan berpengaruh secara langsung maupun tidak langsung terhadap aktor lainnya, dan juga setiap aktor mempunyai fungsi yang berbeda dalam menciptakan suatu rantai nilai yang stabil. Rantai nilai budi daya kolam air tawar di kota bogor dimulai dari petani budi daya kolam ikan air tawar kemudian melalui berbagai tahapan sebelum akhirnya ke konsumen dimana tahapannya dimulai dari pedagang pengepul, pedagang eceran dan pedagang pasar tradisional hingga akhirnya 
sapai pada konsumen. Petani ikan atau pelaku budi daya kolam air tawar merupakan salah satu aktor penting dalam kegiatan rantai nilai, mereka memproduksi ikan yang nantinya akan dijual ke pedagang pengepul. Petani ikan di kota Bogor pada umumnya tidak memasarkan hasil produksi mereka ke pasar tradisional atau ke pedagang besar, mereka menjual ikan hasil panennya ke pedagang pengepul secara borongan dan tidak melalui proses sortasi, seringkali ditemui petani menjual ke pedagang pengepul berdasarkan permintaan jumlah yang diminta oleh pedagang pengepul dan lansung diberikan atau dijual tanpa proses sortasi.

Proses sortasi baru dilakukan pada tingkat pedagang pengepul dimana pada proses sortasi itu pedagang pengepul membedakan berdasarkan ukuran dan kualitas dari ikan tersebut. Kendala pada tingkat petani ikan di Kota Bogor yang paling sering mereka hadapi adalah perubahan cuaca yang berubah secara tibatiba. Pada saat dipagi hari cuaca terlihat cerah, tetapi berubah menjadi hujan deras pada siang atau sore hari. Perubahan cuaca yang cepat membuat petani ikan di Kota Bogor kurang siap dalam mengantisipasi keadaan tersebut secara cepat. Hal itu dikarenakan proses panen dan pasca panen pada tingkat petani mayoritas masih secara tradisional. Pencurian ikan di dalam kolam juga masih sering kali terjadi pada tingkat petani, secara umum petani belum bisa memanfaatkan teknologi dalam pengawasan kolam mereka dikarenakan modal yang dimiliki terbatas. Dengan demikian, pencurian ikan masih sering terjadi sehingga bisa mengurangi hasil panen mereka.

Tingkat selanjutnya adalah pedagang pengepul, pedagang pengepul mempunyai peran mengumpulkan ikan dari petani untuk kemudian dijual kembali ke pedagang besar yang ada di pasar tradisional ataupun kepada pedagang eceran yang akan dijual kembali kepada konsumen akhir. Di tingkat pedagang pengepul dilakukan persortiran ikan yang dilakukan di lahan/ gudang milik pribadi mereka, setelah semua tersortir ikan tersebut akan dibawa oleh mereka ke pasar tradisional ataupun pedagang eceran, selain ke pasar ikan yang sudah disortir oleh pedagang pengepul juga biasanya didistribusikan ke pedagang-pedagang yang menjual makanan olahan ikan, seperti contohnya ke pedagang pecel lele yang ada di pinggir jalan dan pedagang makanan lainnya yang memang sudah menjadi pelanggan tetap dari pedagang pengepul itu sendiri. Pola rantai nilai terkait budi daya kolam ikan

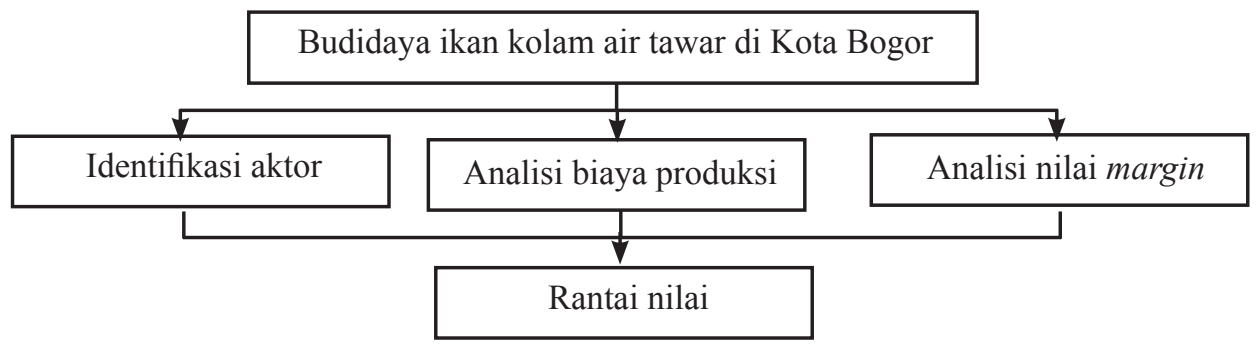

Gambar 1. Kerangka pemikiran penelitian

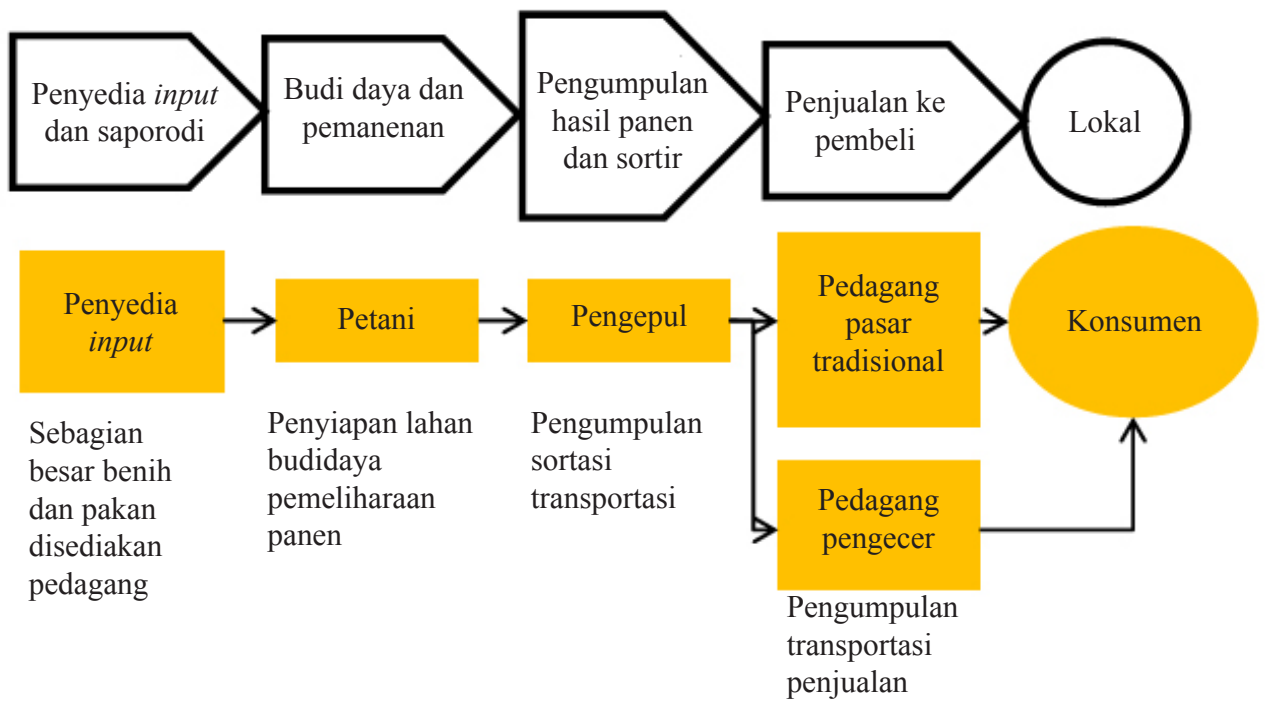

Gambar 1. Kerangka pemikiran penelitian 
air tawar di Kota Bogor dapat dilihat pada Gambar 2.

\section{Identifikasi Aktor}

Aktor-aktor dalam rantai nilai budi daya kolam ikan air tawar di Kota Bogor, yaitu sebagai berikut:

Petani

Petani mempunyai peran yang sangat penting dalam rantai nilai budi daya kolam ikan air tawar ini. Peran petani adalah menghasilkan atau memproduksi ikan air tawar yang pada akhirnya membentuk sebuah rantai nilai di kota Bogor. Pada penelitian terdapat enam orang petani budi daya kolam ikan air tawar di kota Bogor. Petani yang menjadi narasumber pada penelitian ini semuanya berjenis kelamin laki-laki, tingkat pendidikannya beragam mulai dari sekolah dasar sampai dengan lulusan perguruan tinggi. Jenis ikan yang diproduksi pun berbeda-beda setiap petani, akan tetapi dari enam petani yang dijadikan narasumber penelitian ada satu jenis ikan yang sama-sama mereka produksi, yaitu ikan lele.

Ikan lele memang menjadi pilihan bagi hampir setiap petani yang memproduksi ikan air tawar di kota bogor, dikarenakan teknik budi daya yang lebih mudah dibandingkan dengan jenis ikan lainya selain itu juga pasar untuk ikan lele lebih mudah di masuki oleh para petani tersebut.

Tidak setiap petani mempunyai lahannya sendiri untuk memproduksi ikan air tawar ini, pada penelitian ini ada petani yang mengolah/mengerjakan lahan milik orang lain, biasanya petani yang mengolah lahan orang lain menggunakan sistem bagi hasil atau mereka mendapatkan gaji dari pemilik lahan tersebut. Sumber modal yang mereka punya untuk menjalankan usaha budi daya ini berasala dari pribadi, baik itu dari tabungan yang mereka kumpukan sendiri ataupun dari warisan yang memang sudah turun menurun dijalankan, mereka tidak pernah mendapatkan modal dari pinjaman bank, karena untuk mendapatkan modal pinjaman dari bank sangat sulit untuk mereka dapatkan.

\section{Pengepul}

Salah satu aktor lainnya dalam kegiatan rantai nilai ini adalah pedagang pengepul. Kegiatan yang dilakukan oleh pengepul, yaitu pemesanan ikan, penimbangan, pengangkutan, dan pendistribusian ke pasar tradisional atau pedagang pengecer. Pada penelitian ini yang menjadi narasumber pedagang yang berlokasi di kecamatan Bogor Barat, yaitu Bapak Anang. Dalam menjalankan usahanya sebagai pedagang pengepul, Bapak Anang dibantu oleh lima orang pegawainya yang di gajinya secara harian. Setiap bulannya ratarata Bapak Anang dapat mendistribusikan ikan air tawar sebanyak 15 ton setiap bulannya ke pedagang yang sudah menjadi langganan dari Bapak Anang, baik dipasar tradisional maupun pedagang eceran.

Kegiatan distribusi yang dilakukan oleh Bapak Anang tidak hanya diperoleh dari satu petani ikan air tawar saja melaikan dari berbagai sumber yang dicari langsung oleh bapak Anang, berapa jumlah petani yang bisa diambil oleh Bapak Anang tergantung dari permintaan pasarnya dan juga ketersedian dari masing-masing petani langganan Bapak Anang.

Penentuan harga beli ikan yang dilakukan oleh Bapak Anang lebih dominan dari proses tawar menawar, sebagai pedagang pengepul Bapak Anang sudah mempunyai harga patokan yang didapatkan dari harga yang beredar di pasar, kemudian harga tersebut masih bisa ditawar oleh pihak petani sebelum terjadinya proses jual beli antara petani dengan pengepul. Menurut keterangan dari Bapak Anang penetepan standar dalam pembelian ikan air tawar lebih ditentukan oleh pelanggan sendiri, pelanggan menentukan ikan seperti apa yang laku dibeli sehingga dalam memenuhi keinginan pasar Bapak Anang mendapatkan bantuan dari petani dan pedangan pengecer berupa informasi kebutuhan pasar dari produksi yang dilakukan oleh para petani tersebut.

\section{Pedagang}

Aktor yang berperan di hulu dalam kegiatan rantai nilai budi daya ikan air tawar di kota Bogor ini adalah pedagang, baik itu pedagang pengecer maupun pedagang di pasar tradisional. Pedagang ikan di Kota Bogor yang berada di pasar tradisional memang tidak mendapatkan pasokan ikan secara penuh dari pengepul yang ada di Kota Bogor, mereka pun mengambil ikan yang berada di daerah luar kota Bogor yang biasanya sebagian besar dari kabupaten bogor. Banyaknya jumlah permintaan yang didapatkan oleh pedagang di pasar tradisional tidak bisa di penuhi jika pasokan ikannya hanya dari kota bogor saja. 


\section{Margin Rantai Nilai Budi Daya Kolam Ikan Air Tawar}

Secara umum pemasaran hasil panen (ikan hidup) dijual kepada pedagang pedagang pengepul. Pemesanan ikan dilakukan kepada petani yang umumnya dilakukan melalui pesawat telepon. Jika terjadi kesepakatan, dilanjutkan dengan pengiriman order melalui faksimili terkait dengan jumlah yang dibutuhkan dan kepastian harga yang telah disepakati.

Analisis margin rantai nilai dilakukan untuk memperoleh nilai tambah bagi sistem rantai nilai dan setiap aktor yang berada di dalam sistem tersebut. Pada analisis ini dapat dilihat aktor mana yang memiliki margin terbesar dan aktor mana yang memiliki margin terendah. Kondisi ini juga dikaitkan dengan tingjkat risiko yang harus ditanggung oleh pelaku bisnis tersebut. Analisis ini dibagi berdasarkan jenis ikan yang paling banyak di order oleh pedagang pengepul.

Pada Tabel 2 memperlihatkan bahwa harga ikan lele bervariasi di tingkat petani, pengepul, dan pengecer, yaitu masing-masing sebesar Rp16.000, Rp17.500, dan Rp18.500. Margin sama besar antara pengepul dan pihak pengecer (Rp1.500/kg). Biaya panen dan pengangkutan yang dikeluarkan oleh pengepul sebesar Rp500/kg. Biaya promosi dikeluarkan oleh pengecer dimana besarnya biaya tersebut adala $\mathrm{Rp} 500 / \mathrm{kg}$. Sehubungan hal itu, margin yang diterima pengepul dan pengecer berturut-turut sebesar Rp1.500 dan Rp1.500. Harga ikan nila bervariasi di tingkat petani, pengepul, dan pengecer, yaitu masing-masing sebesar Rp18.500, Rp21.000, dan Rp23.000. Margin terbesar adalah dari pengepul ke pihak pengecer (Rp2.500/kg) (Tabel 3). Biaya panen dan pengangkutan yang dikeluarkan oleh pengepul sebesar Rp500/kg. Biaya promosi dikeluarkan oleh pengecer dimana besarnya biaya tersebut adala Rp500/kg. Dengan demikian, margin yang diterima pengepul dan pengecer berturut-turut sebesar Rp2.500 dan Rp1.000.

Tabel 4 memperlihatkan bahwa harga ikan nila bervariasi di tingkat petani, pengepul, dan pengecer, yaitu masing-masing sebesar Rp45.000, Rp48.500, dan Rp50.000. Margin terbesar adalah dari pengepul ke pihak pengecer (Rp3.500/kg). Biaya panen dan pengangkutan yang dikeluarkan oleh pengepul sebesar Rp500/kg. Biaya promosi dikeluarkan oleh pengecer dimana besarnya biaya tersebut adala Rp500/kg. Margin yang diterima pengepul dan pengecer berturutturut sebesar Rp3.500 dan Rp1.500.

Berdasarkan analisis margin dari ketiga 3 jenis ikan di Kota Bogor secara umum, aktor yang memiliki margin paling tinggi adalah pengepul. Hal tersebut dikarenakan pada tingkatan pengepul, pengepul yang melakukan kegiatan penyortiran dan mencarikan pasar dimana ikan tersebut akan disalurkan sehingga mereka yang mempunyai peran komunikasi dua arah, sedangkan aktor lainnya hanya mendapatkan komunikasi sehara tentang pendistribusian ikan.

Tabel 2. Analisis margin budi daya kolam ikan air tawar di Kota Bogor jenis ikan lele

\begin{tabular}{lcccc}
\hline \multirow{2}{*}{ Uraian $(\mathrm{Rp})$} & \multicolumn{4}{c}{ Aktor dalam rantai nilai } \\
\cline { 2 - 5 } & Petani & Pengepul & Pengecer & Konsumen \\
\hline Harga Beli $(\mathrm{Rp} / \mathrm{kg})$ & & 16.000 & 17.500 & 18.500 \\
Biaya $(\mathrm{Rp} / \mathrm{kg})$ & & 500 & 500 & \\
Keuntungan $(\mathrm{Rp} / \mathrm{kg})$ & & 1000 & 1.000 & \\
Margin $(\mathrm{Rp} / \mathrm{kg})$ & & 1.500 & 1.500 & \\
Harga Jual $(\mathrm{Rp} / \mathrm{kg})$ & 16.000 & 17.500 & 18.500 & \\
\hline
\end{tabular}

Tabel 3. Analisis margin budi daya kolam ikan air tawar di Kota Bogor jenis ikan nila

\begin{tabular}{lcccc}
\hline \multirow{2}{*}{ Uraian $(\mathrm{Rp})$} & \multicolumn{4}{c}{ Aktor dalam rantai nilai } \\
\cline { 2 - 5 } & Petani & Pengepul & Pengecer & Konsumen \\
\hline Harga Beli $(\mathrm{Rp} / \mathrm{kg})$ & & 18.500 & 21.000 & 23.000 \\
Biaya $(\mathrm{Rp} / \mathrm{kg})$ & 500 & 500 & \\
Keuntungan $(\mathrm{Rp} / \mathrm{kg})$ & & 2.000 & 1.500 & \\
Margin $(\mathrm{Rp} / \mathrm{kg})$ & & 2.500 & 1.000 & \\
Harga Jual $(\mathrm{Rp} / \mathrm{kg})$ & 18.500 & 21.000 & 23.000 & \\
\hline
\end{tabular}


Tabel 4. Analisis margin budi daya kolam ikan air tawar di Kota Bogor jenis ikan gurame

\begin{tabular}{lcccc}
\hline \multirow{2}{*}{ Uraian $(\mathrm{Rp})$} & \multicolumn{4}{c}{ Aktor dalam rantai nilai } \\
\cline { 2 - 5 } & Petani & Pengepul & Pengecer & Konsumen \\
\hline Harga beli $(\mathrm{Rp} / \mathrm{kg})$ & & 45.000 & 48.500 & 50.000 \\
Biaya $(\mathrm{Rp} / \mathrm{kg})$ & 500 & 500 & \\
Keuntungan $(\mathrm{Rp} / \mathrm{kg})$ & & 3000 & 1.000 & \\
Margin $(\mathrm{Rp} / \mathrm{kg})$ & & 3.500 & 1.500 & \\
Harga jual $(\mathrm{Rp} / \mathrm{kg})$ & 45.000 & 48.500 & 50.000 & \\
\hline
\end{tabular}

\section{Struktur Biaya dan Pendapatan Petani}

Dari wawancara dengan petani diperoleh gambaran mengenai struktur biaya budi daya ikan kolam air tawar dengan ukuran kolam $7 \mathrm{~m} \times 10 \mathrm{~m} \times 1 \mathrm{~m}$ per waktu panen dari tiga jenis ikan yang di panen. Struktur biaya budi daya ikan kolam air tawar dilihat pada Tabel 5.

Petani ikan pada saat panen mengansumsi rata-rata tingkat kematian ikan lele sebesar 30\% dengan meng produksi sebsebanyak $300 \mathrm{~kg}$ dan harga jual sebesar Rp16.000/kg, maka penerimaan petani dari penjualan ikan lele adalah sebesar Rp4.800.000 $(3.000 \mathrm{~kg}$ x Rp16.000). Apabila penerimaan ini dikurangi dengan biaya produksi diatas, maka pendapatan bersih yang diterima petani untuk 1 kolam ukuran $7 \mathrm{~m} \times 10 \mathrm{~m} \times 1 \mathrm{~m}$ per waktu panen adalah sebesar Rp2.085.000.

Petani ikan pada saat panen mengansumsi rata-rata tingkat kematian ikan gurame sebesar 20\% dengan memproduksi sebanyak $280 \mathrm{~kg}$ dan harga jual sebesar Rp45.000/kg. Oleh karena itu, penerimaan petani dari penjualan ikan gurame adalah sebesar Rp12.600.000 (280 kg x Rp45.000). Apabila penerimaan ini dikurangi dengan biaya produksi maka pendapatan bersih yang diterima petani untuk 1 kolam ukuran $7 \mathrm{~m} \times 10 \mathrm{~m} \times$ $1 \mathrm{~m}$ per waktu panen adalah sebesar Rp4.330.000. Pendapatan sebesar Rp4.330.000 yang diterima oleh petani kelihatannya cukup besar, tetapi apabila dilihat dari waktu tunggu petani selama 9 bulan waktu panen ikan gurame, mendapatkan pendapatan sebesar itu sebenarnya petani hanya mendapatkan Rp481.111/ bulan untuk 1 kolam.

Petani ikan pada saat panen mengansumsi ratarata tingkat kematian ikan nila sebesar 20\% dengan memproduksi sebsebanyak $400 \mathrm{~kg}$ dan harga jual sebesar Rp18.500/kg, maka penerimaan petani dari penjualan ikan nila adalah sebesar Rp7.400.000 (400 $\mathrm{kg} \times \mathrm{Rp} 18.500)$. Apabila penerimaan ini dikurangi dengan biaya produksi diatas, maka pendapatan bersih yang diterima petani untuk 1 kolam ukuran $7 \mathrm{~m} \times 10 \mathrm{~m}$ x $1 \mathrm{~m}$ per waktu panen adalah sebesar Rp4.230.000. Pendapatan dari kolam yang di isi oleh ikan nila lebih besar daripada ikan lainnya, menurut petani saat wawancara ikan nila persentase hidupnya lebih banyak jumlahnya daripada lele, dan juga waktu tunggu panen ikan nila tidak begitu lama walapun tidak secepat lele.

Jumlah pendapatan tersebut relatif kecil untuk menutupi kebutuhan bulanan keluarga petani. Hasil dari panen ikan tersebut hanya cukup untuk menutup biaya kebutuhan sehari-hari, dan belum bisa untuk mendapatkan aset baru, dan memenuhi kebutuhan lainnya. Para petani berpendapat minimal mempunyai 3 sampai dengan 4 kolam dengan ukuran yang sama baru mereka bisa memenuhi kebetuhan lainnya.

Berdasarkan ketiga jenis ikan budi daya tersebut, selain harga ikan dipasaran, hal yang memengaruhi dari segi pendapatan petani adalah kondisi ikan saat panen, efisiensi dalam penggunaan pakan ikan dan juga tingkat kematian ikan. Penggunaan pakan yang berlebihan akan menaikan biaya produksi, biasanya para pelaku budi daya akan mencari pakan alternatif untuk mengurangi biaya produksi seperti misalnya penggunaan bangkai ayam ataupun cacing tanah yang dicari sendiri. Selain itu juga jika tingkat kematian ikan tinggi maka penerimaan petani akan rendah. Sarana infrastruktur untuk budi daya kolam air tawar di Kota Bogor secara umum cukup mendukung. Penanganan dan penyimpanan ikan hingga sampai ke konsumen merupakan faktor yang sangat penting untuk mempertahankan kualitas ikan agar tidak cepat mengalami kemunduran mutu (Bao et al. 2007). 
Tabel 5. Struktur biaya produksi ikan lele

\begin{tabular}{|c|c|}
\hline Uraian & Harga (Rp) \\
\hline \multicolumn{2}{|l|}{ Ikan lele } \\
\hline Pembelian bibit lele; 3.000 ekor; Rp125 & 375.000 \\
\hline Pembelian pakan ; 8 sak; Rp280.000 & 2.240 .000 \\
\hline Obat; Rp100.000 & 100.000 \\
\hline Total & 2.715 .000 \\
\hline \multicolumn{2}{|l|}{ Ikan gurame } \\
\hline $\begin{array}{l}\text { Pembelian bibit gurame; } 1.400 \text { ekor; } \\
\text { Rp1.600 }\end{array}$ & 2.240 .000 \\
\hline Pembelian pakan; 21 sak; Rp280.000 & 5.880 .000 \\
\hline Obat; Rp150.000 & 150.000 \\
\hline Total & 8.270 .000 \\
\hline \multicolumn{2}{|l|}{ Ikan nila } \\
\hline Pembelian bibit nila; 2000 ekor; Rp135 & 270.000 \\
\hline Pembelian pakan; 10 sak; Rp280.000 & 2.800 .000 \\
\hline Obat; Rp100.000 & 100.000 \\
\hline Total & 3.170 .000 \\
\hline
\end{tabular}

\section{Implikasi Manajerial}

Hasil pemetaan rantai budi daya kolam air tawar di Kota Bogor dan penentuan faktor yang menentukan keunggulan kompetitif budi daya ikan air tawar di Kota Bogor yang telah dilakukan mendapatkan rekomendasi strategi progresif. Artinya, organisasi dalam kondisi prima dan mantap sehingga sangat dimungkinkan untuk terus melakukan ekspansi, memperbesar pertumbuhan dan meraih kemajuan secara maksimal.

Pengembangan tekhnik budi daya yang konvensional perlu dilakukan, semakin sempitnya lahan pertanian di Kota Bogor harus dipecahkan solusinya, salah satu cara yang bisa dilakukan oleh para pelaku budi daya ikan, khusunya untuk ikan lele bisa dengan menggunakan budi daya kolam terpal bersistem bioflok. Bioflok adalah kumpulan dari berbagai organisme (bakteri, jamur, algae, protozoa, cacing, dan lain-lain) yang tergabung dalam gumpalan (flok). Teknologi bioflok pada awalnya merupakan adopsi dari teknologi pengolahan limbah lumpur aktif secara biologi dengan melibatkan aktivitas mikroorganisme (seperti bakteri). Keuntungan penerapan teknologi bioflok antara lain: seedikit pergantian air (efisien dalam penggunaan air), tidak tergantung sinar matahari, padat tebar lebih tinggi (bisa mencapai $3000 \mathrm{ekor} / \mathrm{m}^{3}$ ), produktivitas tinggi, efisiensi dalam pemanfaatan lahan, membuang limbah lebih sedikit, ramah lingkungan.

\section{KESIMPULAN DAN SARAN}

\section{Kesimpulan}

Rantai nilai budi daya ikan kolam air tawar di Kota Bogor secara umum melibatkan tiga aktor utama, yaitu petani ikan, pengepul dan pedagang. Beberapa hal yang menjadi kendala yang memengaruhi Rantai nilai budi daya ikan kolam air tawar di Kota Bogor antara lain keterbatasan lahan pertanian di Kota Bogor menjadi kendala utama bagi Kota Bogor untuk menambah produksi ikan air tawarnya. Keterbatasan modal para pelaku usaha budi daya yang hanya mengandalkan modal pribadi saja dan sulitnya mendapatkan pinjaman modal dari pihak lembaga keuangan. Hal ini membuat para pelaku rantai nilai budi daya ikan kolam air tawar sulit untuk mengadopsi tekhnologi dari hasil penelitian dari berbagai macam lembaga peneliti. Secara umum pada rantai nilai budi daya ikan ini yang mendapatkan margin terbesar ada pada aktor pengepul, dimana pengepul yang mempunyai akses dan informasi dua arah, baik itu informasi pasar ataupun informasi mencari petani ikan.

\section{Saran}

Saran yang dapat diberikan antara lain perlu adanya kerja sama yang sinergis antara pelaku dalam rantai nilai budi daya ikan kolam air tawar dengan didukung oleh pemerintah daerah dan hasil penelitian dari lembaga penelitian yang tidak dapat diadopsi oleh pembudidaya secara langsung perlu dijembatani oleh Pemerintah Daerah agar dapat diserap dalam rangka mendukung peningkatan produksi ikan air tawar.

Saran untuk penelitian selanjutnya adalah diperlukan penelitian lebih lanjut untuk memperdalam analisis rantai nilai dengan cara menganalisis rantai nilai satu perusahan di Kota Bogor dan dilihat kelayakan usaha/ investasi pada usaha budi daya ikan kolam air tawar.

\section{DAFTAR PUSTAKA}

Arvianto A. 2013. Usulan strategi untuk meningkatkan dayasaing produk mebel rotan single chair dengan analisis rantai nilai (studi kasus: klaster mebel rotan Kab. Cirebon). Jurnal Teknik Industri 8(2): 133-142

[BPS] Badan Pusat Statistik. 2015. Produk domestik bruto atas dasar harga konstan menurut lapangan 
usaha (miliar rupiah), 2000-2014. http://Www. Bps.Go.Id/Linktabelstatis/View/Id/1672. Januari 2015].

[BPS] Badan Pusat Statistik. 2015. Laju pertumbuhan kumulatif menurut lapangan usaha, 2000-2014. http://Www.Bps.Go.Id/Linktabelstatis/View/ Id/1672 [31 Januari 2015].

Bao HND, Arason S, Anna K, Iorarinsdottir. 2007. Effects of dry ice and superchilling on quality and shelf life of arctic charr (Salvelinus alpinus) fillets. International Journal of Food Engineering 3(3): 1-27. https://doi.org/10.2202/15563758.1093 .

Cahyono B. 2001. Budidaya Ikan di Perairan Umum. Yogyakarta: Kanisius.

Hadiwidjojo C. 2016. Rantai nilai pada cv. Master sentra boga. Jurnal Manajemen Bisnis 4(1): 51-59.

Kusumawati A, Purbayu BS. 2013. Rantai nilai (value chain) agribisnis labu di kecamatan getasan Kabupaten Semarang. Universitas Diponegoro Journal of Economics 2(4): 1-10.
Mmasa JJ, Msuya EE. 2012. Mapping of the sweet potato value chain linkages between actors, process and activities in the value chain: a case of michembe and matobolwa products. Sustainable Agriculture Research 1(1):130-148. https://doi. org/10.5539/sar.v1n1p130.

Pambudi BS. 2012. Analisis rantai nilai untuk menentukan strategi daya saing produk manisan carica Dieng. Industrial Engineering Online Journal 1(2): 12-24.

Shank JK, Govindarajan V. 2000. Strategic Cost Management and the Value chain. USA: Thomson Learning

Sokib N. 2012. Strategi peningkatan konsumsi ikan di Kota Depok, Jawa Barat. Jurnal Manajemen Pengembangan Industri Kecil Menengah 7(2): 166-171.

Urbasa PA. 2015. Dampak kualitas air pada budi daya ikan dengan jaring tancap di Desa Toulimembet Danau Tondano. Jurnal Budidaya Perairan 3(1): 59-67. 